\title{
ASPECTOS ÉTICO-LEGAIS DA RETIRADA E TRANSPLANTE DE TECIDOS, ÓRGÃOS E PARTES DO CORPO HUMANO*
}

\author{
Elenice Dias Ribeiro de Paula Lima** \\ Myrian Biaso Bacha Magalhães** \\ Djair Daniel Nakamae***
}

LIMA, E.D.R.P.; MAGALHÃES, M.B.; NAKAMAE, D.D. Aspectos ético-legais da retirada e transplantes de tecidos, órgãos e partes do corpo humano. Rev.latino-am.enfermagem, Ribeirão Preto, v. 5, n. 4, p. 5-12, outubro 1997.

As autoras fazem uma análise crítica da legislação em vigor relativa aos transplantes de órgãos, tecidos e partes do corpo humano, e tecem comentários sobre os artigos pertinentes a eles nos respectivos códigos de ética médica e da enfermagem, alertando os profissionais de enfermagem para a necessidade de registrarem as infrações cometidas contra o cliente, à luz desses códigos.

UNITERMOS: bioética, ética, transplante

\section{INTRODUÇÃO}

Desde a Antigüidade, o interesse do homem pelo seu corpo e pelo dos outros pode ser comprovado através de escritos filosóficos, teológicos, médicos e de enfermagem, que documentam os cuidados, as experiências e as curiosidades do homem em relação aos tecidos do corpo humano, segmento corporal ou orgão em particular, nos diversos períodos históricos.

Se destacarmos o tecido hematopoiético como exemplo, encontraremos registros de que "os povos primitivos untavam-se, banhavam-se e bebiam o sangue de jovens e bravos guerreiros para se beneficiarem de suas qualidades" JUNQUEIRA ${ }^{16}$. Hoje sabemos que a célula sangüínea é um elemento vital ao homem e imprescindível à manutenção da vida, possuindo elementos constitutivos que beneficiam o organismo no qual é transfundido. Essa transfusão para alguns autores, dentre os quais COLLINS ${ }^{10}$, é um transplante de órgão que envolve adaptação do receptor, riscos, bem como inúmeros benefícios.

Dentre as primeiras experiências terapêuticas com o sangue, temos registrado o seu emprego desde séculos passados, quando foi obtido de três jovens para dar vida ao moribundo Papa Inocêncio VIII. Essa experiência não obteve sucesso por ter sido totalmente empírica. Em 17 de dezembro de 1666, Richard Lower, um pesquisador que estudava as possibilidades de se passar o sangue de um animal para outro, publicou os resultados de seus trabalhos no Philosophical transactions. No ano seguinte, em 22 de julho, Jean Denis, professor de Filosofia e Matemática em Montpellier, médico de Luis XIV, fez um relato sobre uma transfusão de sangue de animal para homem, com ocorrência de reação hemolítica. Devido ao óbito de um paciente em 1668, Denis teve que responder ao processo movido pela viúva, gerando a suspensão das experiências hemoterápicas por um grande período, até dezembro de 1818, quando a primeira transfusão sangüínea de um homem para outro foi realizada por Blundell, em Londres. JUNQUEIRA $^{16}$.

BOLLINGER $^{2}$ relata que algumas lendas sobre a ocorrência de transplante em seres humanos datam de 300 a.C., como por exemplo, um documento chinês registrando que "um médico chinês abriu o estômago de dois homens, explorou o coração e, após remover e trocar seus órgãos, administrou-lhes uma droga maravilhosa que os recuperou". Esse mesmo autor relata também a lenda dos médicos Cosme e Damião: amputaram a perna de um homem com problemas vasculares, enquanto este dormia em uma capela destinada a estes santos, sendo que a perna reimplantada havia sido retirada de um

\footnotetext{
* Trabalho final apresentado à disciplina "Bioética e Práxis da Enfermagem” do Programa de Mestrado da Escola de Enfermagem da UFMG

** Docentes do ENB da Escola de Enfermagem da UFMG discentes do programa de Mestrado da EEUFMG

*** Professor Titular da USP, professor visitante do Programa de Mestrado da EEUFMG. Orientadora do trabalho
} 
cadáver enterrado naquele dia. Após o procedimento, o homem conseguiu deambular normalmente.

Várias descobertas foram surgindo no campo médico, e as experiências de transplantar órgãos em animais se intensificaram a partir do século XX.

Dá-se o nome de alotransplante ao transplante entre diferentes membros da mesma espécie. Xenotransplante se refere ao transplante entre membros de diferentes espécies.

O transplante de órgãos vascularizados — rim, fígado, coração, pulmão, pâncreas e intestino - tornouse possível quando foram desenvolvidas técnicas de anastomose vascular. O primeiro transplante renal de longo funcionamento foi descrito por Emerich Ullmann, em março de 1902. Transplantou rins em cães, usando sondas de tubo de magnésio e ligaduras para fazer as anastomoses vasculares. Em 1906, Jaboulay tentou realizar dois xenotransplantes renais, de um porco e de uma cabra, para pacientes com insuficiência renal crônica. Em 1909, Unger tentou transplantar rim de macaco em um homem

Os primeiros homotransplantes - de humano para humano - foram de córneas, realizados por volta de 1880 , segundo ROCHA ${ }^{18}$. Este autor, bem como SABISTON $^{19}$, relata a ocorrência do primeiro homotransplante renal em 1936, efetuado por um médico russo, Ivoronoy, na Ucrânia, que, devido ao desconhecimento dos princípios de transplantologia hoje denominados "Protocolo para Transplante" resultou em insucesso, com óbito do receptor 48 horas após o ato anestésico-cirúrgico. Os dois autores divergem quanto à data, um afirmando ser 1936, e outro, 1933, ficando o período de 1933 a 1949 com relatos de 6 tentativas malsucedidas. ROCHA ${ }^{18}$, no entanto, aponta o ano de 1954, na cidade de Boston - EUA, como marco para a realização do primeiro transplante renal com sucesso, em gêmeos idênticos; mas percebemos, pela literatura consultada - ROCHA ${ }^{18}$; SPINSANTI $^{22}$; SABISTON $^{19}$-, que há divergência quanto à data precisa desse acontecimento.

Em 1905, Carrel e Guthrie foram os pioneiros na realização de transplante cardíaco, de um cão para o outro, na Universidade de Chicago.

Em 1967, Christian Barnard, desconhecido cirurgião de um hospital sul-africano, da Universidade de Cape Town, tornou-se o precursor dos transplantes cardíacos, de humano para humano, bem-sucedidos.

No Brasil, a era dos transplantes teve início no Hospital das Clínicas da USP, na década de 60, sendo hoje, essa instituição, um centro de referência e de desenvolvimento de tecnologia em determinadas áreas de transplante em nível nacional e internacional.
O grande avanço no campo farmacológico, com a descoberta de medicamentos imunossupressores, possibilitou a minimização do problema da rejeição do órgão transplantado, mas ainda existem inúmeras barreiras a transpor, consolidando a máxima de que é inesgotável o campo do saber e do conhecimento humano.

No Estado de Minas Gerais (MG), a área de transplantes tem história bem recente. A Secretaria de Estado da Saúde criou a Coordenadoria do MGTransplante através da Resolução SES/MG n. 131, de 16 de junho de 1989. Este órgão explicita no seu Regimento Interno, Capítulo 1, "Denominação e Finalidades", art. $3^{\circ}$, que a Coordenadoria dará assistência às seguintes áreas e especialidades: coração; pulmão; córnea; fígado; medula óssea; rim; imunogenética ${ }^{20}$.

Os dados do MG - Transplante, em maio de 1995, referentes ao período de 1992 a 1994 são os seguintes:

\begin{tabular}{l|c|c|c|c|c}
\hline ano & $\begin{array}{c}\mathbf{n}^{0} \text { de } \\
\text { do açóes } \\
\text { de } \\
\text { órg ãos } \\
\text { de } \\
\text { cadáueres }\end{array}$ & $\begin{array}{c}\mathbf{n}^{0} \text { de } \\
\text { do açóes } \\
\text { de órgãos } \\
\text { de } \\
\text { individuos } \\
\text { vivos }\end{array}$ & $\begin{array}{c}\text { to tal de } \\
\text { do açóes } \\
\text { feitas }\end{array}$ & $\begin{array}{c}\text { to tal de } \\
\text { transplantes } \\
\text { realizados }\end{array}$ & $\begin{array}{c}\text { órgão } \\
\text { doado }\end{array}$ \\
\hline $\mathbf{1 9 9 2}$ & 128 & 107 & 235 & 247 & rim \\
\hline $\mathbf{1 9 9 3}$ & 149 & 102 & 251 & 251 & rim \\
\hline $\mathbf{1 9 9 3}$ & $*$ & $*$ & 91 & 180 & cómeas \\
\hline $\mathbf{1 9 9 4}$ & 98 & 86 & 184 & 184 & rim \\
\hline TOTAL & 375 & 295 & 761 & 862 & \\
\hline
\end{tabular}

* Não constam se é de doador vivo ou de cadáver

No mesmo período, na área de transplante cardíaco, há registro de 30 transplantes realizados. Quanto ao transplante de fígado, apenas 6 foram realizados na cidade de Belo Horizonte, até abril de 1996.

\section{O problema}

Apesar de na área biomédica os conhecimentos e a tecnologia incorporados aos transplantes já possuírem critérios internacionais seguros, bem como alto percentual de êxito nas intervenções, as áreas ética e jurídica ainda possuem lacunas e geram controvérsias, necessitando de maiores estudos. Na área ética, enfocar-se-á as infrações ao código de ética dos profissionais de enfermagem, pelo enfermeiro, referentes ao cuidado com o corpo dos indivíduos vivos e cadáveres; na área jurídica, os direitos da pessoa e de seus representantes legais. É importante ressaltar que o desenvolvimento de técnicas que proporcionem maiores vantagens em relação aos 
transplantes, para alguns autores como ESCRIBANO ${ }^{11}$, diminui as resistências legais e os problemas ético-morais. Este mesmo autor considera determinante o aspecto técnico, uma vez que este aspecto condiciona os outros, pois com a evolução da técnica, procedimentos considerados arriscados passam a ser rotineiros. Na visão das autoras, entretanto, esta opinião não pode ser aceita passivamente, uma vez que outros fatores altamente complexos estão envolvidos, como custo social, comércio de órgãos, envolvimento de familiares, e outros tais como os que GARRAFA ${ }^{13}$ afirma:

"A questão do mercado humano é muito antiga e na era dos transplantes ela foi apenas aprimorada, avançando de questões mais amplas como a escravidão, a prostituição ou a exploração física do trabalho, para aspectos mais sutis, delicados e específicos de compra, venda ou aluguel de órgãos e estruturas separadas do corpo das pessoas" (GARRAFA, 1993, p. 115).

Trabalhando em centro cirúrgico, percebemos muitas vezes grande ansiedade em doadores de rins, no período que antecede a cirurgia, com exceção dos casos em que a relação é mãe doadora ${ }^{\circledR}$ filho receptor, fato que nos chama a atenção e cremos ser merecedor de maiores investigações, considerando-se as dimensões antropológicas. Na literatura consultada, não encontramos relatos de situações como esta.

O objetivo deste trabalho é efetuar uma análise crítica da legislação vigente relativa aos transplantes de órgãos, tecidos e partes do corpo humano e discutir alguns artigos do Código de Ética dos Profissionais de Enfermagem e do Código de Ética Médica, analizando as implicações legais para estes profissionais.

\section{AS INTERFACES DOS TRANSPLANTES NA ÁREA BIOMÉDICA}

Desde as primeiras tentativas até os dias de hoje, o fenômeno dos transplantes assume características que estão intimamente ligadas ao ato: provocam emoções profundas e ampla repercussão na opinião pública, debate apaixonado entre opiniões divergentes sobre a liceidade moral e as repercussões sociais e econômicas desse procedimento, bem como coloca em evidência exasperante os protagonistas - equipe, doador, receptor, família.

A problemática do candidato a transplante diante das restrições impostas pelo órgão deficiente, na satisfação de suas atividades/necessidades de vida diária elementares a qualquer ser humano, é desencadeadora de emoções nos familiares e na própria equipe de saúde.
A esta situação é acrescida a problemática do doador e de sua família.

São enfocados pela imprensa os desejos, os medos e as dificuldades de ambos - doador e receptor —, quando se processam matérias jornalísticas sobre os transplantes. Percebe-se, entretanto, pouca abordagem de outros aspectos ligados aos transplantes, como a existência de formas de coação dos doadores não explicitadas, sutis, derivadas da passividade das pessoas, em decorrência dos momentos de crise por que passam. GARRAFA $^{13}$, em artigo publicado na revista Bioética do Conselho Federal de Medicina (CFM), levanta esta questão de forma clara:

“...É imprescindivel também que se discuta se os neologismos introduzidos por médicos, advogados, filósofos, comunicadores e economistas têm sido úteis no combate às diferentes formas de mercado ou se, pelo contrário, foram criados e embutidos na linguagem oficial exatamente como subsídio para abertura e ampliação de formas modernas e mais diplomáticas e insinuantes de um novo e florescente "mercado humano brando" (GARRAFA, 1993, p 115).

Existem diversas matérias sobre os procedimentos técnicos para se proceder a transplantes, e os tratados científicos abordam inúmeros capítulos sobre cada órgão, com as recomendações especiais. Há restrições quanto aos transplantes e doações de órgãos entre indivíduos vivos, no sentido de implicarem em mutilações.

Existem leis e os "protocolos para transplantes", específicos para cada tipo de doador e de órgão a ser doado, aceitos universalmente; entretanto, ROCHA $^{18} \mathrm{e}$ FRANÇA $^{12}$ qüestionam a doação de órgãos em vida, reforçando que os transplantes de órgãos de cadáver devem merecer, por parte da sociedade, um interesse ainda maior.

O Decreto n. 879/93 em seu art. 15, garante ao doador desistir da doação sem explicações:

"A decisão do doador não poderá sofrer influência que lhe vicie o consentimento, sendo-lhe facultado revogar o consentimento dado, até a extração dos orgãos, tecidos ou partes do seu corpo, sem necessidade de justificar ou explicar suas razões". ${ }^{4}$

\section{OS ASPECTOS LEGAIS DO TRANSPLANTE}

A luta do homem pela superação de seus limites é cada vez maior. As diferentes áreas da medicina têm buscado incessantemente vencer a luta contra o 
envelhecimento e a morte; procurado explicar e controlar a fecundação e a gestação, bem como bloquear os processos patológicos que acarretam óbitos. Sentimos que, atualmente, poucos são os limites estabelecidos para que o homem não prossiga nessa caminhada, e ela tem ultrapassado, inúmeras vezes, os limites morais, éticos e jurídicos, no que tange ao respeito pelo ser humano.

Os transplantes têm gerado conflitos na área jurídica, pois LANA ${ }^{17}$ aborda que, apesar de serem de inqüestionável caráter humanitário, as controvérsias são de tal vulto que superam, em muito, a capacidade da sociedade para assimilar tal progresso de imediato. Essa autora afirma que o ideal seria que a ordem jurídica procurasse se antecipar, regulando possíveis situações que pudessem ocorrer a médio prazo, tendo em vista o atual estágio das pesquisas tecnológicas. Reforça, ainda, que desta forma evitar-se-iam os transtornos e as perplexidades diante do fato consumado. Considera que isto é utópico ainda, uma vez que o Direito tem sempre trabalhado com as dificuldades que as novas realidades suscitam, quando estas já estão incorporadas ao meio social.

A primeira lei brasileira a regular o tema dos transplantes de órgãos foi a de n. 4280/63, sendo revogada pela $2^{\mathrm{a}}$ lei de n. 5.479/68. Esta lei, segundo LANA ${ }^{17}$, deixou em aberto as discussões, pois o seu art. $1^{\circ}$ declara: "A disposição gratuita de uma ou várias partes do corpo, post-mortem, para fins terapêuticos, é permitida na forma desta lei". Já o art. 10 dispõe: "É permitido à pessoa maior e capaz dispor de órgãos e partes do próprio corpo vivo, para fins humanitários e terapêuticos". Não há, nesta lei, a palavra "gratuidade", não havendo, portanto, imposição para que esta condição ocorra.

A lei mais recente sobre transplantes é a de n. 8 489/92, regulamentada pelo decreto n. 879/93, que procurou corrigir as distorções dos artigos $1^{\circ}$ e 10 da lei n. 4.280/63. O artigo 12 ficou assim explicitado: “ $E$ permitida à pessoa maior e capaz dispor gratuitamente de órgãos, tecidos ou partes do próprio corpo vivo para fins humanitários e terapêuticos",

FRANÇA $^{12}$,comentando a lei 8501 de 30/11/92, afirma que:
"o veto presidencial ao artigo $2^{\circ}$ deixou a lei sem uma definição clara da morte, pois a Resolução n. 1 346/91 do CFM especificava o conceito encefálico de morte baseado no exame clínico e em, pelo menos, um tipo de exame complementar sobre a parada total e irreversível das funções encefálicas" (FRANÇA, 1994, p. 74)

Ao analisarmos a legislação vigente sobre os transplantes e a Resolução n 1 346/91 do Conselho Federal de Medicina, que dispõe sobre critérios de morte encefálica, em seus princípios adotados, item 2 - "o período de observação desse estado clínico deverá ser de, no mínimo, 6 (seis) horas" - percebemos que há divergência em relação aos aspectos éticos discriminados nos protocolos para transplante, analisados no decurso deste trabalho, pois o art. $6^{\circ}$ do Capítulo V do Regimento Interno do Núcleo de Transplantes de coração/pulmão cita:

"A captação de doadores de coração elou pulmão será feita por uma equipe multiprofissional que se incumbirá de: (...) d) agilizar a efetivação do diagnóstico clínico e confirmação da morte cerebral do doador,"21.

A palavra "agilizar", na opinião das autoras, gera mal-estar, pois adquire conotação discutível e perigosa quando se aborda a eutanásia, parecendo estar antecipando o diagnóstico de morte cerebral e isto, ainda, quando analisamos o tempo exigido para efetuar esses transplantes, que é de 2 horas após a morte, contrapondose à resolução do CFM de observar por 6 horas, através de dois EEG feitos neste espaço de tempo.

Alguns juristas, discutindo a lei atual dos transplantes de órgãos, fazem algumas considerações importantes:

A lei não pode ser totalmente fechada; as aberturas são para permitir os procedimentos considerados inovadores, embora tenham deixado transparecer o receio de serem retirados os órgãos da pessoa ainda em vida.

Existem dois valores a serem preservados: a vida, devendo o doador ser escrupulosamente respeitado; e a dignidade do cadáver, pois este não é um objeto, uma coisa; apesar de simultaneamente estar sujeito à destruição, deve ser cercado de respeito, pois o cadáver continua tendo a qualidade humana da pessoa à qual pertenceu.

As leis se orientam para preservar ao máximo a vida humana, devendo-se adotar o transplante como conduta terapêutica quando não houver outro tratamento possível, sendo claro, no caso de doação em vida, que não deverá e não poderá haver prejuízo evidente do doador, como, por exemplo, no caso de rins, doar os dois órgãos.

O indivíduo menor de idade é considerado incapaz, pois o que ele decide sobre si não tem valor para atos de disposição. Nos casos em que o pai não tem autoridade sobre o filho, é necessária autorização judicial.

O doador deve estar ciente dos riscos. A lei não obriga ao ato de heroísmo, mas também não o impede. Se a pessoa quiser se sacrificar por amor, ela poderá fazêlo.

Existe a presunção de que os atos praticados pelos indivíduos adultos são atos livres; entretanto, se a pessoa é iludida, ou se é um psicopata, os atos podem ser considerados inconsistentes, estando sujeitos à 
responsabilidade civil, e até à penal, aqueles que induziram ou iludiram o doador.

A validade do "termo de responsabilidade" que o paciente assina dependerá de a pessoa estar "consciente" do que está fazendo ao assiná-lo. Se é menor ou pessoa sem condições de compreendê-lo, o que assina não tem validade legal.

Na cultura brasileira, a pessoa não pode dispor de seu corpo como dispõe de um objeto seu; a lei brasileira não permite o comércio de órgãos. O indivíduo que ajuda outrem a suicidar, no Brasil, ainda não é punido pela lei, visto que o sistema penitenciário não prevê condições especiais para este tipo de pena. O que é "instituído" é a não punição da tentativa de suicídio, visando "não aumentar a aflição do aflito".

Durante a elaboração desse trabalho, foram entrevistados alguns juristas, e esses relataram não terem tido até aquele momento, nenhuma causa de defesa ou de acusação - sobre a utilização indevida de cadáver não reclamado, para fins de estudo em faculdades, principalmente de corpos resultantes de ação criminosa, conforme cita a Lei n. $8501 / 92$, art. $3^{\circ}$, incisos 1 e 11 , $\S \S$ $1^{\circ}, 2^{\circ}, 3^{\circ}$ e $4^{\circ}$.

O professor Ruben $\mathrm{CIONE}^{7}$ faz um comentário à lei dos transplantes, num estudo intitulado "Interior Transplante" do Hospital das Clínicas da Faculdade de Medicina de Ribeirão Preto - USP, São Paulo. Nesse documento, o autor supra-citado afirma que:

"o art. $2^{\circ}$ da Lei $n$. 5.479, que disciplina os transplantes de órgãos e tecidos, outorga a disposição gratuita de uma ou várias partes do corpo depois de estabelecer a prova incontestável da morte. Dessa forma, não houve nenhuma preocupação do legislador em definir o que seja essa prova incontestável, deixando ao sabor de quem verifica o óbito o critério que melhor lhe convenha” (...) não foram respeitados os critérios emitidos pela OMS e pela UNESCO, pois, além de exigirem condições técnicas e humanas de operabilidade, indicam também determinados critérios para que se estabeleça a morte. Afastou-se ainda, nossa legislação, dos meios de diagnóstico e de um tempo mínimo para que se definisse o óbito" (CIONE, s/d, p.13).

Considerou-se que este documento é bastante veemente, abordando os aspectos mais capciosos da lei. $\mathrm{O}$ autor afirma ter muita responsabilidade, o legista, ao opinar sobre a causa diante de morte violenta, de forma imediata, no laudo médico-legal, sem a devida apuração do inquérito policial judiciário. Relata, como exemplo, um caso ocorrido em Barcelona, em 1986, quando um legista se recusou a certificar o óbito de um motorista ao notar a falta de rins ao cadáver, que já tinham sido inclusive, transplantados em duas outras pessoas.

O Decreto n $879 / 93^{3}$, com fins no art. 10, $\S 3^{\circ}$, regulamenta: "É vedado à equipe médica responsável pela retirada de tecidos, órgãos ou partes do corpo a realização de atos médicos que possam prejudicar o diagnóstico da causa mortis pelo médico-legista".

As fundamentações dos juristas são vastas e consubstanciadas, entretanto, as leis ainda não conseguiram captar todas as interfaces existentes; e parece oportuno deixar aqui registrada uma afirmação de Antônio Chaves apud LANA ${ }^{17}$.

"O que se refere à matéria é, afinal de contas, o sentido de moralidade que prevalece numa determinada época, o sentimento dos bons costumes do homem médio que está, no entanto, sofrendo uma rápida evolução nestes últimos dez anos" (LANA, 1994, p. 4).

\section{ASPECTOS ÉTICOS DOS TRANSPLANTES}

A ética é definida, pela Igreja Católica, como " $o$ conjunto das atitudes e ações humanas, apreciadas sob o ponto de vista do bem e do mal" ANTONIAZZI ${ }^{1}$.

SPINSANTI ${ }^{22}$ faz considerações sobre a etimologia dos termos "deontologia" e "ética", afirmando que a deontologia não se propõe a guiar a consciência dos indivíduos para o bem moral, não se preocupa com a qualidade moral da ação , sendo normas estabelecidas pelos próprios profissionais, depois de atenta reflexão sobre a prática cotidiana, embasando-se no que favorece ou prejudica a profissão. Para ele, há diferença entre ética e moral. A ética se refere à consideração fideista do problema do bem e do mal, ligado à revelação divina, à religiosidade.

Percebe-se hoje a ética com vários enfoques. Segundo GELAIN ${ }^{14}$, para a visualização de uma conformação ética, o ponto fundamental são os valores que variam de pessoa a pessoa, de grupos para grupos, e em cada época acerca que ética "é a ciência do comportamento moral dos homens em sociedade".

A priori, aceita-se como preceito ético a não discriminação de doadores e receptores quanto a sexo, idade, raça, religião, nacionalidade, quer por parte de enfermeiros, quer por outros profissionais de saúde. O artigo 47 do Código de Ética Médica - CFM/ $/ 88^{9}$ - é explícito quanto à proibição de discriminação do ser humano, de qualquer natureza ou sob qualquer pretexto.

A ocorrência de discriminação deve ser denunciada ao Conselho Regional de Enfermagem, na visão das autoras desse trabalho, quando indivíduos de raças discriminadas socialmente forem usados em benefício de outras raças, ou de sexos também desvalorizados, em benefício de outros. O art. 21 do 
Código de Ética dos Profissionais de Enfermagem COREN SP $/ 93^{8}$ - capítulo IV - dos Deveres, cita: "é dever do enfermeiro cumprir e fazer cumprir os preceitos éticos e legais da profissão". No art. 27 explicita que o enfermeiro deve "Respeitar e reconhecer o direito do cliente de decidir sobre sua pessoa, seu tratamento e seu bem-estar". Já o art. 30 diz que o enfermeiro deve "colaborar com a equipe de saúde no esclarecimento do cliente e família sobre o seu estado de saúde e tratamento, possíveis benefícios, riscos e consequüências que possam ocorrer".

Ao analisar esses artigos, percebe-se serem uma área de conflito na enfermagem, na percepção das autoras, pois são mais trabalhados pela enfermagem os aspectos relacionados aos benefícios enquanto que os riscos e as consequiências são pouco abordados. Alguns profissionais omitem informações ao paciente, justificando tal conduta pela explicação de minimizar os fatores geradores de estresse face à proximidade do transplante, para não gerar insucesso do ato cirúrgico decorrente de estado psicológico inapropriado.

Cremos que alguns trabalhos poderiam ser realizados no sentido de fundamentar os problemas encontrados, bem como a melhor forma de trabalhá-los.

$\mathrm{O}$ art. 32 "Respeitar o ser humano na situação de morte e pós-morte", também é área de conflito para o enfermeiro. Muitas instituições não possuem lugar determinado e decente para recebimento do cadáver e nem se preocupam em garantir o material mínimo para um bom preparo, delegando a responsabilidade ao serviço funerário, onde o corpo é tratado como mercadoria e material a ser preparado e despachado o mais depressa possível. Nem sempre se percebe a utilização das medidas de biossegurança no manuseio de cadáveres, mesmo quando este apresenta sangue e secreções corpóreas.

O artigo 39 diz que é dever do enfermeiro "Alertar o profissional quando diante de falta cometida por imperícia, imprudência, negligência". Percebemos, no entanto, que nas relações de trabalho já dificultadas por inúmeros fatores intervenientes, este artigo nem sempre é seguido pelo enfermeiro.

O artigo 46 explicita que é proibido ao enfermeiro "promover a eutanásia ou cooperar em prática destinada a antecipar a morte do cliente".

Cremos que é dever do médico ligar e desligar aparelhos vitais e, como conduta médica, não deve e não pode ser repassado ao profissional de enfermagem, correndo o risco de ser denunciado por "negligência"e, o enfermeiro, por "conivência"com o ato.

O professor João Batista Vilella* discutindo o art. 66 do Código de Ética de Enfermagem, em palestra sobre legislação dos transplantes, para mestrandos da Escola de Enfermagem da UFMG, salientou que o profissional não pode ser considerado cúmplice só por fazer parte da equipe.

França apud GOGLIANO ${ }^{15}$ afirma que

"o médico não pode dispor

incondicionalmente da vida de seu paciente a ponto de obrigá-lo a aceitar uma conduta terapêutica, a não ser diante de iminente perigo de vida (...) Nos transplantes, deve o médico informar ao doente todos os riscos operatórios, as possibilidades de êxito e a duração possível de sua sobrevivência" (GOGLIANO, 1993, p.148).

Um outro aspecto ético que merece discussão, na visão das autoras, é o tempo para a realização dos transplantes. A lei $8.501 / 92^{6}$ e ROCHA $^{18}$ relatam que os órgãos têm prazos diferenciados para serem transplantados:

Rim - o prazo é de até 6 horas após a morte.

Coração e pulmão - prazo máximo de 2 horas após a morte.

Córneas - a equipe deverá ser notificada até 2 horas após a doação, devendo o transplante ocorrer no prazo máximo de 6 horas.

Esse aprazamento, na visão das autoras, chocase com a legislação que prevê a confirmação de morte cerebral através de exames comprobatórios, em número de duas repetições, com espaço de tempo de 6 horas um do outro. Torna-se, assim, difícil ajustar-se a ambos os critérios.

\section{CONSIDERAÇÕES FINAIS}

A questão dos transplantes ainda merece mais estudos e discussões entre a população científica e leiga.

Focalizando o custo social dos transplantes, gostaríamos de citar PESSINI ${ }^{18}$ quando chama a atenção para a alta tecnologia e o alto custo dos transplantes, ao lado de milhares de pessoas que morrem de doenças endêmicas já há muito superadas pela medicina: "Ganha manchete em jornais e revistas a criança que não sobreviveu ao transplante de fígado e, no entanto, a que morreu porque não tinha o que comer (...) junta-se à legião dos anônimos".

Compreendemos que o exercício da profissão dentro dos princípios ético-legais é um exercício da cidadania. O enfermeiro deverá intensificar sua atitude de vigilância e garantia desses princípios, participando com o cliente e a comunidade de discussão acerca de manipulações discretas de grupo corporativistas.

\footnotetext{
* Professor Titular do Departamento de Direito Civil e Comercial da Faculdade de Direito da Universidade Federal de Minas Gerais
} 
Chamou-nos a atenção o fato de a maioria dos documentos jurídicos consultados não explicitar de forma contundente as penalidades e deveres específicos da enfermagem ou do enfermeiro. Surgiram indagações que, cremos, devam ser mais aprofundadas nos textos legais, tais como:

Quais as garantias legais para se conscientizar os candidatos à doação, em relação a espaço físico reservado, composição da comissão de recrutamento, nível de escolaridade, etc?

Quais os procedimentos legais exigidos do profissional enfermeiro para documentar qualquer ato ilícito que presenciar, visando instauração de denúncia ética ou legal?

Têm sido formadas e efetivamente fiscalizadas as "comissões de ética médica e de enfermagem" nas instituições?

Finalizando, cremos ser pertinente uma afirmação de SPINSANTI ${ }^{22}$ :

"O caminho para o futuro da humanidade procede por um labirinto de corredores possíveis, que não podem ser estabelecidos de vez, mas devem ser constantemente submetidos ao vigilante controle da consciência moral" (SPINSANTI, 1990, p. 163).

\section{CONCLUSÃO}

As autoras concluem que:

A questão dos transplantes é dicotômica em relação à legislação, uma vez que a situação de morte cerebral exige dois exames comprobatórios, num espaço de tempo de 6 horas um do outro e os protocolos para transplantes preconizam prazos menores, tornando-se, assim, difícil ajustar-se a ambos os critérios.

Impera a necessidade de melhor conscientização sobre a doação de órgãos, tanto no que diz respeito à necessidade dessas doações, quanto aos riscos, às vantagens e ao custo social.

Não existe explicitação na legislação vigente de como o enfermeiro poderá defender-se nos casos em que a instituição onde trabalhar não compuser adequadamente o cadáver (quando existir serviço de preparo que não for de sua supervisão direta), ou quando houver intercorrências durante o transporte do cadáver e o corpo não for entregue decentemente à família, pois ele assina o termo de responsabilidade técnica pela instituição, no COREN.

Existe necessidade de problematizar fatos concretos vivenciados pela enfermagem, para que o enfermeiro seja capaz de atitudes profissionais compromissadas com o cliente e a comunidade, exercendo seu efetivo papel social e político, promovendo mudanças comportamentais e a transformação da sociedade.

As autoras avaliam que há premência na realização de estudos que detectem intercorrências vivenciadas pelos enfermeiros no preparo e transporte do corpo e existência de conflitos com a família da vítima.

\section{LEGAL-ETHICAL ASPECTS OF THE REMOVAL AND TRANSPLANTATION OF TISSUES, ORGANS AND PARTS OF THE HUMAN BODY}

The authors analise critically the current legislation related to the transplantation of organs, tissues and parts of the human body, as well as they comment the articles which refer to this topic and which are found in medical and nursing ethical codes, advising nursing professionals to the need of registration of legal infractions attempted against the clients.

\section{ASPECTOS ÉTICO-LEGALES DE LA RETIRADA Y TRANSPLANTE DE TEJIDOS, ORGANOS Y PARTES DEL CUERPO HUMANO}

Las autoras hacen un analisis crítico de la legislación en vigor referente a los transplantes de órganos, tejidos y partes del cuerpo humano y hacen comentarios sobre los artículos pertinentes a ellos en los respectivos códigos de ética médica y de enfermería, alertando a los profesionales de enfermería sobre la necesidad de registrar las transgresiones hechas contra el cliente, a la luz de esos códigos. 